\title{
Performance of late season litchi cultivars grown in Jharkhand Province of India
}

\author{
B.R. Jana* \\ ICAR, Research centre for Makhana, Basudeopur, Darbhanga-846005 ( Bihar), India \\ Bikash Das \\ ICAR-RCER, Research Centre Plandu, Ranchi-834010 (Jharkhand), India \\ Rajvir Sharma \\ ICAR, Research centre for Makhana, Basudeopur, Darbhanga-846005 ( Bihar), India \\ B.P. Bhat \\ ICAR-RCER, Bihar Veterinary College Campus, Patna- 800014 (Bihar), India \\ *Corresponding author. E-mail: brjana.ars@gmail.com
}

\begin{abstract}
The narrow genetic diversity and short market availability of litchi (Litchi chinesis Sonn.) are the main constrains for its cultivation more profitable in Indian sub-continent. Late season litchi cultivars in subtropical and tropical India are prone to fruit cracking and diseases susceptibility. Seven promising selections and four late season commercial cultivars viz; CHES-1, CHES-2, CHES -3, CHL-5. CHL-7, Lal Bombaiya, Late Bedana, Purbi, Selection -3-7, Selection 8-1 and Swarna Roopa were evaluated during 2014-15 at ICAR-RCER Ranchi, based on physico-chemical characters, cracking habit and diseases susceptibility. The results revealed that the cultivars Purbi, Lal Bombaiya and Late Bedana were cracking resistant. The maximum fruit weight was found in the cultivars Lal Bombaiya $(22.0 \mathrm{~g})$ being comparable with Late Bedana $(21.2 \mathrm{~g})$ and CHES-2 $(21.0 \mathrm{~g})$. The cultivars Lal Bombaiya and CHES -2 had the highest aril weight of $19.44 \mathrm{~g}$ and $17.66 \mathrm{~g}$, respectably. The maximum TSS of $22.2{ }^{\circ} \mathrm{B}$ was found in CHES- 1 both in Jharkhand and Bihar. Late Bedana cultivar had high sugar acid ratio (73.52) with pomegranate flavor and popular for local market. Litchi fruit borer mainly attacked Lal Bombaiya and CHES-2 at early stage whereas the cultivars Purbi and Swarna Roopa were affected (3-6\% bunch) by litchi stink bug (Tessaratoma javanica) at late harvest season. From the present study, it was concluded that CHES-1, Lal Bombaiya, Purbi and Late Bedana were promising late season cultivars for commercial cultivation with effective management of litchi fruit borer and stink bug.
\end{abstract}

Keywords: Diseases, Fruit cracking, Late season, Litchi, TSS

\section{INTRODUCTION}

Delicious, juicy and tasty lychee or "litchi" heralds us the arrival of summer in the Indian subcontinent. Besides being sweet and nutritious, these berries bring cooling effect on the human body to beat the scorching summer heat. Botanically, this exotic fruit belongs to the family of Sapindaceae, and taxonomically known as (Litchi chinensisSonn.).It is one of the most important subtropical evergreen summer fruits grown in India. Bihar is the largest producer of litchi followed by West Bengal, Western U.P. Jharkhand and Punjab. Guangdong Province is the most important area for lychee production in China. Other provinces where lychee grows well include Guangxi, Fujian, Hainan and Yunnan (Chen and Huang, 2000). It is planted in sub-mountainous tracts of northern and eastern India since, it likes mild climate with sufficient humidity during its following and fruiting.
Litchi is very delicious fruit and is very much liked by the consumer during summers. It is generally consumed as a fresh fruit. Litchi fruits have no competition from other fruits as it comes in the market in May-June and faces no marketing problem. Litchi is believed to be originated in southern China stretching from Northern Vietnam to Malaysia where it has been cultivated for thousands years back. Litchi is very fastidious to soil and climatic requirements and thrives well under certain latitudes. The primary centre of origin of litchi fall under $23-27{ }^{0}$ North latitudes that generally covered Southern China, Northern Vietnam and Malaysia. Already, Through breeding efforts the major production zones are distributed in such a way that good quality fruits are available both in November-December (Australia) Menzel (2001) and May-August (India, China, Taiwan Province of China, Thailand). The experience of Israel, Taiwan Province of China and Mauritius has shown 
that further lengthening of the fruiting season is possible. Oligonol, a low molecular weight polyphenol, is found abundantly in lychee fruit. Oligonol is thought to have anti-oxidant and antiinfluenza virus actions. Also, it helps improve blood flow to organs, reduce weight, and protect skin from harmful UV rays Sakurai (2008). Further, it is a very good source of B-complex vitamins such as thiamin, niacin, and folates. These vitamins are essential since they function by acting as co-factors to help the body metabolize carbohydrates, protein, and fats. Litchi also carries a very good amount of minerals like potassium and copper. Potassium is an important component of cell and body fluids that helps to control heart rate and blood.

Litchi (Litchi chinensis Sonn.) belongs to the family Sapindaceae is an evergreen, subtropical fruit tree, native to South China. It has been grown for as long as 1766 B.C. (Menzel,2001). China is the leading litchi producing country in the world with an annual productionof 950,000 tons but other countries such as South Africa, Israel, Madagascar, Mauritius, USA, Australia India, Pakistan, the Philippines, Thailand, Taiwan, Indonesia, Vietnam and Brazil also have considerable production of litchi (Menzel, 2001; Lemmer, 2002). According to Sawe, (2018), litchi production in the World was more than 4,92,500 tones and major litchi producing countries were China, Taiwan and India. In India, at present, the area of litchi cultivation is 84,000 hectares and production is 5,94,000 MT (NHB, 2015). The litchi fruit is a good source of nutrition and is also rich source of vitamins $C$ (Wall, 2006) and phenolic compounds that have antioxidant activities ( $\mathrm{Hu}$ et al., 2010) but it may decrease after harvest ( Taylor, 1993 ). Keeping above point in view the present experiment was conducted on the late cultivars of litchi germplasm of ICAR-RCER, Research Center Ranchi to identify suitable late cultivars for commercial cultivation in future at large scale.

\section{MATERIALS AND METHODS}

The experiment was conducted at ICAR Research Complex for Eastern Region, Research Centre, and Ranchi during 2014-15. This area is situated $620 \mathrm{~m}$ above mean sea level (msl) and at $23^{\circ} 25^{\prime}$ $\mathrm{N}$ latitude and $85^{\circ} 20^{\prime}$ East longitude experiencing an average annual rainfall of $110-140 \mathrm{~cm}$. Soil is acidic and $\mathrm{pH}$ ranges from 5.0-6.5, which is ideal for litchi cultivation. Each cultivar was considered the treatments $\mathrm{T}_{1}=\mathrm{CHES}-1, \mathrm{~T}_{2}=$ CHES-2, $\mathrm{T}_{3}=$ CHES-3, $\mathrm{T}_{4}=\mathrm{CHL}-5, \mathrm{~T}_{5}=\mathrm{CHL}-7, \mathrm{~T}_{6}=$ Lal Bombaiya, $T_{7}=$ Late Bedana, $T_{8}=$ Purbi, $T_{9}=$ Selection 3$7, T_{10}=$ Selection 8-1 and $T_{11}=$ Swarna Roopa. Data on fruit weight and colours and seed weight and peel weight, specific gravity (mass/vol) were taken as by standard methods. Total soluble solid (TSS) was measured by ATAGO Digital hand Refracto meter (Range 0-50\%) and written as ${ }^{0} \mathrm{~B}$ which reflects $\%$ of soluble solids. Titratable acidity was estimated by titrating the fruit extract with $0.1 \mathrm{~N}$ $\mathrm{NaOH}$ using phenolphthalein as an indicator and expressed as per cent citric acid equivalent. Total sugars and Reducing sugars were estimated by Lane and Eynon method as described by Hand book of quality analysis of Fruits and Vegetables and their processed products (Ranganna, 1996). Peel Strength was measured through penitrometer readings and expressed as $\mathrm{kg} / \mathrm{cm}^{2}$. Boron content of the peel was determined by Chemical methods and calculated and expressed as $\mathrm{mg} / 100$ gm peel weight following Hunt and Shuler method (Hunt et al., 1991). Samples were taken from three plants of each of the cultivars representing treatments. Data were analyzed by taking ANOVA from the Randomized Block Design (RBD) trial. Pest and disease infestations were measured by checking infected fruits during harvesting and expressed them in per cent.

\section{RESULTS AND DISCUSSION}

Physico-chemical changes: A close perusal of the Table-2 revealed that the cv. Lal Bombaiya $(22.0 \mathrm{~g})$ accounted for the maximum fruit weight of followed by Late Bedana (21.2 g). Lal Bombaiya was dark red in colour while Late Bedana looked dull red in colour. However, the maximum TSS of $22.2{ }^{0} \mathrm{~B}$ was observed in CHES- 1 being comparable with Selection-8-1, CHL5 and Lal Bombaiya and Purbi $\left(20.0^{\circ} \mathrm{B}\right)($ Table-3). Similar findings were also observed by Rahman et al., (2015) regarding TSS of Purbi and Late Bedana and Haq and Rab (2012) regarding TSS of Gola, China, Surahi and Bedana, which were 20.39, $19.49,22.13$ and 16.27 per cent, respectively. In present study, flattened tubercles were found in Lal Bombaiya and Late Bedana cultivars. The maximum aril weight was found in Lal Bombaiya (19.44g) and CHES-2 $(17.66 \mathrm{~g})$. The maximum seed weight of $(3.50 \mathrm{~g})$ was examined in cultivar Swarna Roopa but maximum peelweight of $4.0 \mathrm{~g}$ was measured in case of cv.Purbi. This study corroborates the findings obtained by Sharma and Roy (1987) while working on China and Bedana and other cultivars under Bihar condition India. It has been observed that the maximum total sugar was present in cultivar CHES-1 (15.62 g) which was statistically at par with Selection $8-1(15.27 \mathrm{~g})$. This result was in corroborated with the findings of Ghaffoor et al (1999) where Bedana had highest Total sugar $11.6 \%$. Although the cultivar CHES -1 had the maximum acidity of $0.208 \%$, it possessed the highest sugar acid ratio of 75.26 which was statistically at par with Late Bedana(73.52) (Table-3). Results obtained from chemical characteristics are more or less similar as the results obtained by the Ghosh et al.,(1988) on Bedana, Bombay, Muzaffarpur, Early Large Red and Nagarpal and Mc 
Table 1. Prominent late litchi cultivars of the world and their characters.

\begin{tabular}{lllll}
\hline SI. No. & Late cultivars & Fruit weight $(\mathbf{g})$ & TSS $\left({ }^{0} \mathrm{~B}\right)$ & Time of harvest and Country \\
\hline 1. & Bosewarh-3 & 22.0 & 21.3 & Late June Australia \\
2. & Groff & 12.0 & 20.3 & Late in Hawaii \\
3. & Late Bedana & 18.0 & 21.2 & Early June India \\
4. & Nomici & 20.0 & 21.0 & Late June to August China \\
\hline
\end{tabular}

Ref: Wood (2004) Goenaga et al (2016) *Late Bedana : Present study

Table 2. Performance of late season litchi cultivar grown in Jharkhand Province of India during 2014-15.

\begin{tabular}{|c|c|c|c|c|c|c|c|}
\hline Cultivars & $\begin{array}{l}\text { Average } \\
\text { TSS }\left({ }^{\circ} \mathrm{B}\right)\end{array}$ & $\begin{array}{l}\text { Average } \\
\text { Colour }\end{array}$ & $\begin{array}{l}\text { Tuber- } \\
\text { cles }\end{array}$ & $\begin{array}{l}\text { Average } \\
\text { fruit } \\
\text { weight (g) }\end{array}$ & \multirow[t]{2}{*}{$\begin{array}{l}\begin{array}{l}\text { Average } \\
\text { seed } \\
\text { weight } \\
\text { (g) }\end{array} \\
2.12\end{array}$} & $\begin{array}{l}\text { Average } \\
\text { peel weight } \\
\text { (g) }\end{array}$ & $\begin{array}{l}\text { Average } \\
\text { aril } \\
\text { weight } \\
\text { (g) }\end{array}$ \\
\hline CHES-1 & 22.2 & Red & Pointed & 17.0 & & 1.62 & 13.25 \\
\hline CHES-2 & 19.5 & Red & Pointed & 21.0 & 1.42 & 1.90 & 17.66 \\
\hline CHES -3 & 19.5 & Red & Pointed & 18.5 & 1.81 & 2.42 & 14.25 \\
\hline CHL-5 & 20.0 & Yellow & Pointed & 18.5 & 1.45 & 0.96 & 16.08 \\
\hline CHL-7 & 20.2 & Red Yellow & Pointed & 20.0 & 1.67 & 1.63 & 16.69 \\
\hline Lal Bombaiya & 20.0 & Red & Flattened & 22.0 & 1.55 & 1.07 & 19.44 \\
\hline Late Bedana & 18.0 & Dull Red & Flattened & 21.2 & 2.03 & 2.63 & 16.54 \\
\hline Purbi & 20.0 & Red Pointed & Pointed & 17.5 & 3.00 & 4.00 & 10.51 \\
\hline Selection 3-7 & 18.0 & Reddish yellow & Pointed & 19.5 & 1.25 & 2.16 & 16.08 \\
\hline Selection 8-1 & 21.5 & Red & Pointed & 16.5 & 1.63 & 1.18 & 13.68 \\
\hline Swarna Roopa & 18.0 & Red & Pointed & 15.5 & 3.50 & 3.00 & 9.02 \\
\hline CD at $5 \%$ & 1.34 & - & - & 1.17 & 0.45 & 0.29 & 1.67 \\
\hline \multicolumn{8}{|c|}{ Table 3. Physico -chemical properties of late litchi cultivars grown in Ranchi during 2014-15. } \\
\hline Cultivars & \multicolumn{2}{|c|}{$\begin{array}{c}\text { Average } \\
\text { TSS }\left({ }^{\circ} \mathrm{B}\right)\end{array}$} & $\begin{array}{l}\text { acidity } \\
\text { \%) }\end{array}$ & \multicolumn{2}{|c|}{$\begin{array}{c}\text { Average } \\
\text { total sugar (\%) }\end{array}$} & \multicolumn{2}{|c|}{$\begin{array}{c}\text { Average } \\
\text { sugar acid ratio }\end{array}$} \\
\hline CHES-1 & \multicolumn{2}{|c|}{22.0} & 208 & \multicolumn{2}{|c|}{15.62} & \multicolumn{2}{|c|}{75.26} \\
\hline CHES-2 & \multicolumn{2}{|c|}{19.5} & 199 & \multicolumn{2}{|c|}{13.40} & \multicolumn{2}{|c|}{70.12} \\
\hline CHES -3 & \multicolumn{2}{|c|}{19.5} & 199 & \multicolumn{2}{|c|}{13.40} & \multicolumn{2}{|c|}{67.33} \\
\hline CHL-5 & \multicolumn{2}{|c|}{20.0} & 189 & \multicolumn{2}{|c|}{14.20} & \multicolumn{2}{|c|}{73.11} \\
\hline CHL-7 & \multicolumn{2}{|c|}{20.2} & 191 & \multicolumn{2}{|c|}{14.34} & \multicolumn{2}{|c|}{75.26} \\
\hline Lal Bombaiya & \multicolumn{2}{|c|}{20.0} & 204 & \multicolumn{2}{|c|}{13.74} & \multicolumn{2}{|c|}{67.33} \\
\hline Late Bedana & \multicolumn{2}{|c|}{18.0} & 184 & \multicolumn{2}{|c|}{12.37} & 73.52 & \\
\hline Purbi & & 0.0 & 204 & 13.7 & & 67.33 & \\
\hline Selection 3-7 & & 8.0 & 170 & 12.7 & & 75.26 & \\
\hline Selection 8-1 & & 1.5 & 203 & 15.2 & & 71.00 & \\
\hline Swarna Roopa & & 8.0 & 189 & 12.5 & & 66.03 & \\
\hline CD at $5 \%$ & & 08 & IS & 1.12 & & 3.26 & \\
\hline
\end{tabular}

Table 4. Harsh weather for pest infestation and cracking in late cultivars of litchi 2014-15.

\begin{tabular}{|c|c|c|c|c|}
\hline Cultivars & $\begin{array}{l}\text { Cracking } \\
(\%)\end{array}$ & Date of harvest & Fruit borer Infestation* & $\begin{array}{l}\text { Litchi Stink Bug Infesta- } \\
\text { tion }(\%)^{*}\end{array}$ \\
\hline CHES-1 & 12.5 & $27 / 5 / 14-04 / 06 / 14$ & Absent & No \\
\hline CHES-2 & 0.0 & $27 / 5 / 14-04 / 06 / 14$ & Natural Resistant & No \\
\hline CHES -3 & 12.5 & $27 / 5 / 14-04 / 06 / 14$ & Absent & No \\
\hline CHL-5 & 7.5 & $24 / 5 / 14-30 / 05 / 14$ & Present (very Less) $<3 \%$ & No \\
\hline CHL-7 & 10.0 & $27 / 5 / 14-04 / 06 / 14$ & Absent & No \\
\hline Lal Bombaiya & 10.5 & $30 / 5 / 14-07 / 06 / 14$ & Present(less)3-6\% & No \\
\hline Late Bedana & 2.5 & $30 / 5 / 14-07 / 06 / 14$ & Absent & No \\
\hline Purbi & 0.0 & $30 / 5 / 14-07 / 06 / 14$ & Natural Resistant & Moderately affected (3-6\%) \\
\hline Selection 3-7 & 10.0 & $24 / 5 / 14-30 / 05 / 14$ & Absent & Present (very less) $<3 \%$ \\
\hline Selection 8-1 & 7.5 & $27 / 5 / 14-04 / 06 / 14$ & Absent & No \\
\hline Swarna Roopa & 10.0 & $30 / 5 / 14-07 / 06 / 14$ & Present (very less) $<3 \%$ & Moderately affected (3-6\%) \\
\hline CD at $5 \%$ & 2.23 & - & - & - \\
\hline
\end{tabular}

lean cultivars, Sharma and Roy (1987) on China and Bedana and others cultivars and Rahman et al.,(2015) on Deshi Early Bedana, late Bedana, Kasba and Purbi cultivars. Sugar acid ratio of Purbi and Late Bebana under Bihar, Bhagalpur condition was 34.75 and 36.81(Rahman et al 2015). A comparative report on world's best late litchi cultivars have been cited in Table-1.
Physiological disorder (cracking) and pest infestation: Fruit cracking in early stage may be due to high temperature and sudden irrigation water or natural down fall. But in case of cracking in late cultivar it mainly due to boron deficiency in the soil ( Baradwaj, 2010). The cultivars CHES-1 and CHES-3 exhibited the maximum fruit cracking of $12.5 \%$. Harsh weather about temperature (Table- 
Jana, B.R. et al. / J. Appl. \& Nat. Sci. 11(1): 12-16 (2019)

Table 5. Relationships among specific gravity, skin strength ,boron content and cracking in late litchi cultivars during 2014-15.

\begin{tabular}{lcccc}
\hline Cultivars & $\begin{array}{c}\text { Average } \\
\text { specific gravity }\end{array}$ & $\begin{array}{c}\text { Average } \\
\text { skin strength(kg/cm2) }\end{array}$ & $\begin{array}{c}\text { Average } \\
\text { boron } \mathbf{~ m g / 1 0 0 g}\end{array}$ & $\begin{array}{c}\text { Average } \\
\text { cracking(\%) }\end{array}$ \\
\hline CHES-1 & 1.096 & 2.02 & 0.111 & 12.5 \\
CHES-2 & 1,018 & 3.44 & 0.150 & 0.0 \\
CHES -3 & 1.095 & 2.00 & 0.112 & 12.5 \\
CHL-5 & 1.021 & 2.02 & 0.109 & 7.5 \\
CHL-7 & 1.074 & 2.63 & 0.108 & 10.0 \\
Lal Bombaiya & 1.087 & 2.47 & 0.109 & 10.5 \\
Late Bedana & 1.049 & 3.26 & 0.130 & 2.5 \\
Purbi & 1.023 & 3.56 & 0.160 & 0.0 \\
Selection 3-7 & 1.068 & 2.19 & 0.128 & 10.0 \\
Selection 8-1 & 1.012 & 2.05 & 0.112 & 7.5 \\
Swarna Roopa & 1.071 & 2.47 & 0.120 & 10.0 \\
CD at 5\% & $\mathbf{0 . 0 4}$ & $\mathbf{0 . 4 2}$ & $\mathbf{0 . 0 2 1}$ & $\mathbf{2 . 2 3}$ \\
\hline
\end{tabular}

Table 6. May Weathers of Ranchi Research Centre (ICAR-RCER)--2014-15 (Internet source).

\begin{tabular}{lllll}
\hline \multirow{2}{*}{ Year } & \multicolumn{2}{c}{ Temperature $\left({ }^{\circ} \mathrm{C}\right)$} & \multicolumn{2}{c}{ Rainfall (mm) } \\
\cline { 2 - 5 } & Highest maximum (Date) & Lowest minimum (Date) & 24 Hours highest/(Date) & Monthly total \\
\hline 2015 & $41.7(25)$ & $18.6(17)$ & $057.6(13)$ & 089.3 \\
2014 & $39.9(23)$ & $19.8(04)$ & $025.0(28)$ & 060.8 \\
\hline
\end{tabular}

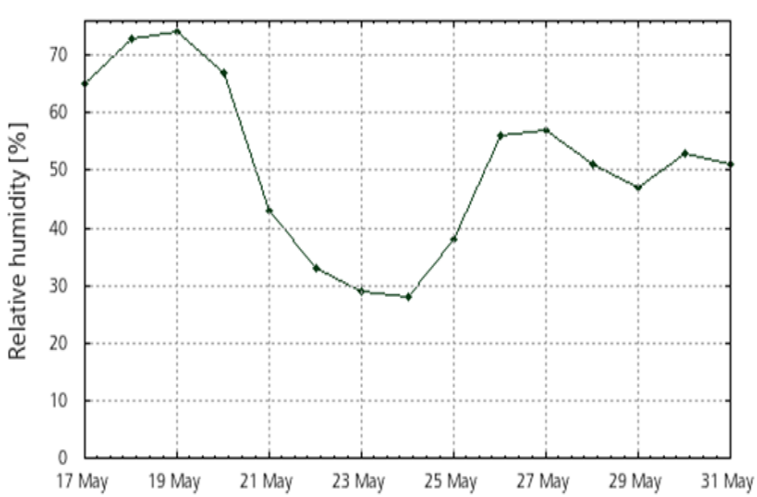

Fig. 1. Humidity data 2014.

6) and humidity (Figs. 1-2) are responsible for fruit cracking in Ranchi. We observed that cracking resistant cultivars like Purbi and CHES-2 are also fruit borer resistant (Table-4). These cultivars were the natural resistant to fruit borer and had the maximum boron content of $0.16 \mathrm{mg}$ and 0.15 $\mathrm{mg} / 100 \mathrm{~g}$ peel (Table-5). The results clearly indicated that any injury (by fruit borer or others) aggravated the fruit cracking disorder. Besides, fruit desiccation and cracking resistance depended on pericarp structure in litchi (Huang et al 2004). In cv. Lal Bombaiya shoot borer infestation was more prominent (3-6\%) than cv. Swarna Roopa. The late litchi cultivars CHES-2 and Purbi had also the highest skin strength of 3.56 and $3.44 \mathrm{~kg} /$ $\mathrm{cm}^{2}$, respectively, which was purely varietal characters.

Litchi stink bug sucks the fruit juice or sap from the peel and leaving black scar on surface which leads to decrease in market acceptability. Litchi stink bug (Tessaratoma javanica), now a day's is a problem to litchi grower of Jharkhnad. It a new pest in litchi growing areas of Jharkhand and $\mathrm{Bi}$ har having host plant nearer to the orchard. The

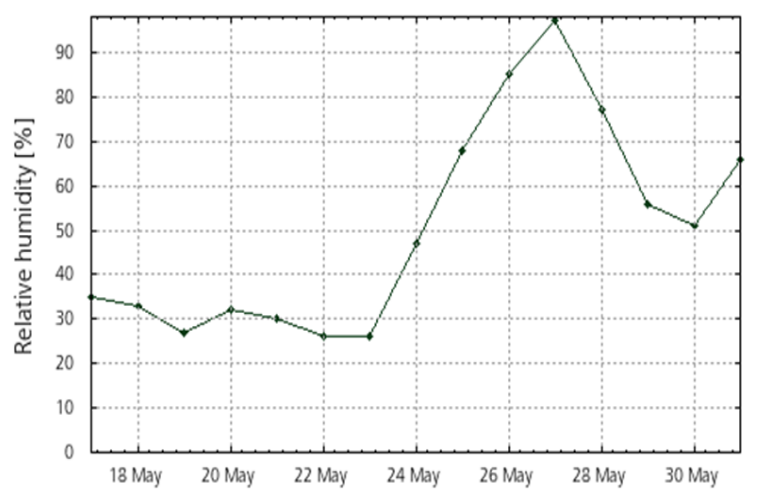

Fig. 2. Humidity data 2015.

cv. Purbi and Swarna Roopa were moderately devastated by the Litchi Stink Bug when infestation rate was $3-6 \%$. This type of attack may be due to no more litchi cultivars were present at last in the orchard. The least infestation of litchi shoot borer was recorded in the cv. Selection 3-7 ( $>3 \%$ ). The cultivar Late Bedana was almost resistant to cracking $(2.5 \%)$ and free from disease and pest infestation.

From the table -5 it is evident that, lower the specific gravity of the fruit causes lower cracking. Higher the boron content of peel and strength of peel is lesser prone to cracking. Harsh weather at Ranchi during May causes fruit cracking and diseases infestation which was aggravated by the higher \% RH during last week of May (Table 6 Fig -1 , Fig-2).

Cracking and post harvest disease: Anthracnose (Colletotrichum gloeosporoides), attacked leaves along with flowers and fruit. Prevailing climatic conditions (high temperature and high relative humidity) were highly conducive for the development and spread of anthracnose disease in litchi. The higher the latent infection rates of an- 
thracnose of the fruits caused more serious the postharvest browning of the fruits. Brown Blight known as blossom blight caused by Peronophythora in litchi attacked its both young and ripe fruits. Higher temperatures during day favored the sporulation, germination and infection of the pathogen. The diurnal variations of temperature and high humidity at night facilitated zoospore release. The disease and pest infestation indicated desiccation of litchi fruits and subsequent browning.

\section{Conclusion}

The late litchi cultivars Purbi, CHES-2 were natural resistant to fruit borer and cracking, which prevented disease infestation in later stage. The cultivar Late Bedana was almost resistant to cracking and free from disease and pest infestation and had large fruit with high sugar acid ratio and sweet scented. The litchi stink bug may also attack late cultivar as the other crops ended at that time in orchards. Fruit aril weight was the good indicator for cracking resistance. The cultivars Lal Bombaiya and CHES -2 had high aril weight but former showed moderate cracking and fruit borer resistant. Therefore, CHES-2, Lal Bombaiya, Late Bedana and Purbi were the promising late season cultivars that could be grown in commercial scale under sub-humid subtropical climate of Ranchi and in adjoining plateau area of Jharkhand. As litchi has big and sound domestic as well as international market, availability of litchi can be effectively extended by selection, introduction, and breeding of late cultivars. By increasing area of cultivation through late cultivars, total production could be increased and farmers would get maximum return from their venture.

\section{REFERENCES}

1. Chen, H. and Huang. H. (2000). China litchi industry: Development, achievements and problems. Abst. 1st Int. Symposium on litchi and longan. Guangzhou, China, p. 18

2. Ghaffoor, A., Rehman, S., Ali, B., Saddozai, M.E. and Waseem, K. (1999). Performance of litchi (Litchi Chinensis Sonn.) cultivars for some morphological, chemical and yield related traits under the agroclimatic conditions of D.I. Khan, Pakistan. Pakistan Journal of Biological Sciences, 2: 503-506.

3. Ghosh, B., Biswas, B,, Mitra, S.K. and Bose, T.K. (1988). Physico-chemical composition of some promising cultivars of litchi adapted in West Bengal. Indian Food Packer. 14: 34-37

4. Ghosh, B., Mitra, S.K. and Sanyal, D. (2000). Litchi cultivars of West Bengal, India. Abst. 1st Int. Sympo- sium on litchi and longan. Guangzhou, China, p. 25.

5. Goenaga, R. Jerkins, D and Marrero, A. (2016). Yield performance of six lychee cultivars grown at two locations in Puerto Rico, HortTechnology 26 (6):748-753

6. Haq, I U and Rub, A. 2012. Characterization of physico-chemical attributes of litchi fruits and its relation with fruit skin cracking. J. Anim. Plant Sci. 22(1):142147

7. Hu, Z.Q., Huang, X.M., Chen, H.B. and Wang, H.C. (2010). Antioxidant capacity and phenolic compounds in litchi (Litchi chinensisSonn.) pericarp. Acta Hort. 863:567-574

8. Huang, X.M., Yuan, W. Q., Wang, C. Li, J.G. Huang, H.B. Shi, L. and Jinhua, Y. (2004). Linking cracking resistance and fruit desiccation rate to pericarp structure in litchi (Litchi chinensis Sonn.). J Hort. Sci. Biotech. 79:897-905.

9. Hunt, C. D., Shuler, T. R. and Mullen, L. M. (1991). Concentration of boron and other elements in human foods and personal-care products. J Am Diet Assoc 91(5): 558.

10.Lemmer, D. (2002). Report on the Chinese litchi industry. S.A. Litchi Growers'Assoc. Yearbook.13:1-4

11.Menzel, C.M. (2001). The physiology of growth and cropping in lychee. South African Litchi Growers' Association Yearbook. 12:9-14

12.NHB [National Horticulture Board], (2015). Second Advance Estimate of Area and Production of Horticulture Crops (2013 - 14).

13.Rahaman, A., Rahaman,T.G. and Das, D.K. (2015). Studies on physico-chemical characteristics of some promising cultivars of Litchi( Litchi chinensis Sonn.) under Bihar plateau condition. AIJRFANS:ISSN (online): 2383-3785: page 1-3

14.Ranganna, S. (1996). Handbook of analysis and quality control of fruit and vegetable products. Tata McGraw Hill Publishing Company New Delhi.

15.Sakurai, T. (2008). Litchi Nutrition (Kyorin University, Japan).Biosci. Biotechnol. Biochem., 72(2), 463476, 2008).

16.Sawe, B.E. (2018). Top lychee producing countries in the World. World Fact. https://www.worldatlas.com/ articles/top-lychee-producing-countries-in-theworld.html

17.Sharma, S.B. and Roy, P.K. (1987). Flowering and fruiting behaviour of some litchi cultivars. Haryana J.Hort.Sci. 16(3\&4): 168-174

18.Taylor, J.E. (1993). Exotics. In: G.B. Seymour, J.E.Taylor and G.A. Tucker (Editors), Biochemistry of Fruit Ripening. Chapman and Hall, London.Pp. 53-82

19.Wall, M.M. (2006). Ascorbic acid and mineral composition of longan (Dimocarpuslongan).Lychee (Litchi chinensis) and rambutan (Nepheliumlappaceum) cultivars grown inHawaii. J. Food Compos.Anal. 19:655-663

20.Wood, M. (2004). New options for lychee and longan fans and farmers ars.usda.gov. USDA Agricultural Research Service. Web. 22 Mar. 2015. 